\title{
Factors associated with increased blood loss during delivery
}

\author{
Paridhi Jain $^{1 *}$, Nisha Thakur ${ }^{1}$, Ashu Jain², Sunita Agrawal ${ }^{1}$, Sangeeta Kamra', Shyla Jacob ${ }^{1}$
}

${ }^{1}$ Department of Obstetrics and Gynecology, Jawahar Lal Nehru Hospital and Research Centre, Bhilai, Chhattisgarh, India

${ }^{2}$ Department of General Surgery, Civil Hospital, Ahmedabad, Gujarat, India

Received: 09 January 2020

Accepted: 05 February 2020

*Correspondence:

Dr. Paridhi Jain,

E-mail: paridhijain908@gmail.com

Copyright: (c) the author(s), publisher and licensee Medip Academy. This is an open-access article distributed under the terms of the Creative Commons Attribution Non-Commercial License, which permits unrestricted non-commercial use, distribution, and reproduction in any medium, provided the original work is properly cited.

\begin{abstract}
Background: The present study was done to assess the blood loss during delivery even after active management of third stage of labor with oxytocin and the maternal outcomes of PPH.

Methods: We studied 100 pregnant women were either in spontaneous labor or admitted for induction of labor, underwent vaginal delivery or caesarean section in our institute. Active management of third stage of labor in all 100 cases included $10 \mathrm{IU}$ intramuscular oxytocin or 10 to $20 \mathrm{IU}$ intravenous in $500 \mathrm{ml}$ of Ringer's Lactate. Blood loss in all cases was noted.

Results: Of the included cases, 27 had to be given extra-uterotonics for atonic uterus, of which 12 parturient still had $\mathrm{PPH}$. Atonic uterus was the cause of PPH in 11 of the 12 cases, while one case was of atonic uterus plus trauma. Half of all PPH cases responded to medical management alone, five cases had to undergo tamponade/stepwise devascularization and one case had to undergo obstetric hysterectomy. Blood loss was significantly higher in women aged more than 35 years, primigravida, not in labor, oligohydramnios or post-datism, elective LSCS, scarred uterus in and had more than 1 high risk factor. Among various high-risk conditions, significantly higher blood loss was observed in patients with chronic hypertension, gestational hypertension, pre-gestational diabetes mellitus, multipara with prior PPH, placenta previa, preeclampsia and sickle cell trait.

Conclusions: Fifteen women avoided PPH by using a reliable method of blood loss measurement and initiating interventions early. Organized PPH management protocol morbidity and mortality of the mother and neonate can be prevented.
\end{abstract}

Keywords: Blood loss, Gravimetric method, Oxytocin, Post-partum hemorrhage, Pregnancy, Uterotonics

\section{INTRODUCTION}

Postpartum haemorrhage (PPH) is a major cause of maternal morbidity and mortality worldwide and is reported to have increased in frequency recently. According to WHO estimates PPH is leading cause of maternal mortality and morbidity worldwide and is responsible for nearly one-quarter $(25 \%)$ of all maternal deaths. ${ }^{1}$ Definitions of PPH vary in different parts of the world but is best defined and diagnosed clinically as excessive bleeding that makes the patient symptomatic (eg, pallor, light-headedness, weakness, palpitations, diaphoresis, restlessness, confusion, air hunger, syncope) and/or results in signs of hypovolemia (eg, hypotension, tachycardia, oliguria, low oxygen saturation. Active management of third stage of labor has been suggested as an effective method of PPH prevention. ${ }^{2}$ There are numerous risk factors which are associated with an increased blood loss during childbirth and are associated with poor maternal outcomes. These factors vary with the geographical location and may be different in high and middle/low income countries. It is mainly because of the interplay of various socio-demographic and economic factors that are associated with poor maternal and 
neonates' outcomes. Therefore, it is necessary to generate country specific data regarding the causes of PPH and maternal outcomes related to it. The present study was done to assess the blood loss during delivery even after active management of third stage of labor with oxytocin and the maternal outcomes of PPH.

\section{METHODS}

In this hospital based observational study we included pregnant women who were either in spontaneous labor or admitted for induction of labor in the department of obstetrics and gynecology, Jawahar Lal Nehru Hospital and Research Centre, Bhilai, Chhattisgarh from November 2017 till November 2018. It is a tertiary care teaching hospital, which caters to the healthcare needs of Bhilai and nearby towns and villages. Selected study participants were explained the purpose of the study and a written consent for participating in the study was obtained before enrolment. The study was approved by the Institutional Ethics Committee.

\section{Sample population}

We conducted a pilot study which revealed a mean blood loss during delivery as $315 \pm 168.86 \mathrm{ml}$. To achieve $5 \%$ confidence levels with a margin of error of $\pm 50 \mathrm{ml}$, we calculated the minimum sample size to be 44 . To increase the reliability and power of the study, we included 100 pregnant women in the study. These women were either in spontaneous labor or admitted for induction of labor, underwent vaginal delivery or caesarean section in our institute. We excluded cases who had period of gestation $<36$ weeks, were already in DIC prior to delivery, deliveries culminating in intrauterine fetal death or those women who delivered outside our hospital.

\section{Data collection and data analysis}

Detailed history and physical examination was done on eligible patients. Active management of third stage of labor in all 100 cases included 10 IU intramuscular oxytocin or 10 to $20 \mathrm{IU}$ intravenous in $500 \mathrm{ml}$ of Ringer's Lactate immediately after anterior shoulder or baby delivery, delayed cord clamping according to recent WHO guidelines 2012, controlled cord traction and routine uterine tone assessment. ${ }^{1}$

Blood loss in vaginal deliveries was calculated by inserting Kelly's pad just after second stage of labor and collecting all blood in graduated jar. All the pads soaked were weighed and difference of wet and dry pads taken into account ( $1 \mathrm{gm}$ equals to $1 \mathrm{ml}$ blood loss). Both the blood collected in jar plus soaked in pads added to get total blood loss. In caesarean sections, blood loss was measured by calculating the fluid collected in suction jar (initial collected amniotic fluid was subtracted). All the mops soaked were weighed and difference of wet and dry pads were taken into account $(1 \mathrm{gm}$ equals to $1 \mathrm{ml}$ blood loss). The amount of blood collected in mattress beneath the patient plus clots collected also measured. All cases were observed for 2 hours more for further blood loss and PPH. Our cut off for diagnosing PPH was $>500 \mathrm{ml}$ in vaginal deliveries and $>1000 \mathrm{ml}$ in caesarean sections.

Cases going in PPH were given medical management as first line of treatment. It included Oxytocin up to $40 \mathrm{IU}$, Methergin $0.2 \mathrm{mg}$ intramuscular maximum of 5 doses, Carboprost of $250 \mu \mathrm{g}$ maximum of 8 doses, Misoprost $800 \mu \mathrm{g}$ per rectal or $600 \mu \mathrm{g}$ sublingual. Newer drugs like Tranexemic acid were also used as per the discretion of the treating surgeon. PPH cases not responding to medical management were further followed up for uterine tamponade or surgical management like stepwise devascularization as second line of treatment and obstetric hysterectomy as third line of management. The maternal outcome in terms of morbidity and mortality was noted.

\section{Statistical analysis}

Data were analyzed in SPSS (version 23 for Windows, IBM). Data were presented descriptively as frequencies. The mean blood loss was calculated in various group of patients and compared using Analysis of Variance or Ftest, using $\mathrm{p}$ value less than 0.05 as statistically significant.

\section{RESULTS}

Table 1: Baseline characteristics of the patients included in the study.

\begin{tabular}{|lll|}
\hline Variable & N & $\%$ \\
\hline Age distribution (in years) & \multicolumn{1}{l|}{} \\
\hline$\leq 20$ & 2 & $2 \%$ \\
\hline 21 to 25 & 23 & $23 \%$ \\
\hline 26 to 30 & 44 & $44 \%$ \\
\hline 31 to 35 & 26 & $26 \%$ \\
\hline$\geq 36$ & 5 & $5 \%$ \\
\hline Gravid status & & \\
\hline G1 & 48 & $48 \%$ \\
\hline G2 & 38 & $38 \%$ \\
\hline G3 & 12 & $12 \%$ \\
\hline$\geq$ G4 & 2 & $2 \%$ \\
\hline Onset of labor & & \\
\hline Induced & 36 & $36 \%$ \\
\hline Spontaneous & 51 & $51 \%$ \\
\hline Not in labor & 13 & $13 \%$ \\
\hline Type of delivery & & \\
\hline Normal vaginal & 50 & $50 \%$ \\
\hline Forceps vaginal & 1 & $1 \%$ \\
\hline Elective LSCS & 5 & $5 \%$ \\
\hline Emeregency LSCS & 44 & $44 \%$ \\
\hline Patients received & & \\
\hline Blood/blood components & 6 & $6 \%$ \\
\hline Tranexemic acid & 9 & $9 \%$ \\
\hline Both & 3 & $3 \%$ \\
\hline
\end{tabular}


During the study period, 100 patients were included. The mean age of all patients was $28.36 \pm 4.1$ years. Table 1 describes the baseline characteristics. Most common age group was 26 to 30 years and $48 \%$ were primigravida. Onset of labor was spontaneous in $51 \%$ of the patients and normal vaginal delivery was done in $50 \%$ of all patients. Of the included cases, 27 had to be given extrauterotonics for atonic uterus (based on the gravimetric method of measuring blood loss), of which 12 parturient still had PPH. Atonic uterus was the cause of PPH in 11 of the 12 cases, while one case was of atonic uterus plus trauma (Table 2). Half of all PPH cases responded to medical management alone, five cases had to undergo tamponade/stepwise devascularization after medical management and one case had to undergo obstetric hysterectomy after medical management/stepwise devascularization. Five of these cases were delivered vaginally and rest underwent LSCS. None of the women in our study went in to DIC/shock/renal failure or died as a result of $\mathrm{PPH}$.

Table 2: Characteristics of women with post-partum hemorrhage $(n=12)$.

\begin{tabular}{|lll|}
\hline Variable & N & $\%$ \\
\hline Cause of PPH & & \\
\hline Atonic & 11 & $92 \%$ \\
\hline Atonic + traumatic & 1 & $8 \%$ \\
\hline Retained placenta & 0 & $0 \%$ \\
\hline Coagulopathy & 0 & $0 \%$ \\
\hline PPH management & & \\
\hline Responding to medical management & 6 & $50 \%$ \\
\hline $\begin{array}{l}\text { Tamponade/stepwise devascularization } \\
\text { after medical management }\end{array}$ & 5 & $42 \%$ \\
\hline $\begin{array}{l}\text { Obstetric hysterectomy after medical } \\
\text { management/stepwise devascularization }\end{array}$ & 1 & $8 \%$ \\
\hline Maternal outcomes & & \\
\hline Anemia & 8 & $67 \%$ \\
\hline Wound gape & 2 & $17 \%$ \\
\hline Lactation failure & 1 & $8 \%$ \\
\hline DIC/shock/renal failure & 0 & $0 \%$ \\
\hline
\end{tabular}

Table 3 describes the association of various patient related variables with the amount of blood loss. The mean blood loss of all the patients included in the study was $480.2 \pm 366.47 \mathrm{ml}$. Blood loss was significantly higher in women of age more than 35 years $(846 \pm 528.6 \mathrm{ml})$, primigravida $(547.2 \pm 402.3 \mathrm{ml})$, those not in labor $(573.08 \pm 239.8 \mathrm{ml})$, those with oligohydramnios $(766.67 \pm 585.95 \mathrm{ml})$ or post-datism $(619 \pm 686.98 \mathrm{ml})$, those who underwent elective LSCS $(700 \pm 257.97 \mathrm{ml})$, had a scarred uterus in $(748.89 \pm 373.2 \mathrm{ml})$ and had more than 1 high risk factor $(654.44 \pm 422.7 \mathrm{ml})$. Various highrisk conditions which persisted in our patients have been described in Table 4.

The most common ones were hypothyroidism $(n=15)$ and preeclampsia $(n=11)$. Significantly higher blood loss was observed in patients with chronic hypertension, gestational hypertension, pre-gestational diabetes mellitus, multipara with prior PPH, placenta previa, preeclampsia and sickle cell trait.

Table 3: Association of various patient related variables with the amount of blood loss.

\begin{tabular}{|c|c|c|}
\hline Variable & $\begin{array}{l}\text { Blood loss in } \\
\mathrm{ml} *\end{array}$ & p value $* *$ \\
\hline \multicolumn{3}{|c|}{ Age distribution (in years) } \\
\hline$\leq 20$ & $445 \pm 134.35$ & \multirow{5}{*}{$<0.001$} \\
\hline 21 to 25 & $514.35 \pm 550.72$ & \\
\hline 26 to 30 & $442.27 \pm 295.6$ & \\
\hline 31 to 35 & $446.5 \pm 193.7$ & \\
\hline$\geq 36$ & $846 \pm 528.6$ & \\
\hline \multicolumn{3}{|l|}{ Gravid status } \\
\hline G1 & $547.2 \pm 402.3$ & \multirow{4}{*}{$<0.05$} \\
\hline $\mathrm{G} 2$ & $400.7 \pm 327.6$ & \\
\hline G3 & $483.3 \pm 318.3$ & \\
\hline$\geq \mathrm{G} 4$ & $260 \pm 197.99$ & \\
\hline \multicolumn{3}{|l|}{ Onset of labor } \\
\hline Induced & $502.22 \pm 436.29$ & \multirow{3}{*}{$<0.05$} \\
\hline Spontaneous & $440.98 \pm 338.6$ & \\
\hline Not in labor & $573.08 \pm 239.8$ & \\
\hline \multicolumn{3}{|c|}{ Indication for labor induction } \\
\hline $\begin{array}{l}\text { Decreased fetal } \\
\text { movement }\end{array}$ & $557.5 \pm 333.9$ & \multirow{7}{*}{$<0.05$} \\
\hline $\begin{array}{l}\text { Hypertensive disorder } \\
\text { of pregnancy }\end{array}$ & $407.5 \pm 202.89$ & \\
\hline $\begin{array}{l}\text { Premature rupture of } \\
\text { membranes }\end{array}$ & $426.43 \pm 189.23$ & \\
\hline Oligohydramnios & $766.67 \pm 585.95$ & \\
\hline $\begin{array}{l}\text { Intra-uterine growth } \\
\text { restriction }\end{array}$ & $465 \pm 445.48$ & \\
\hline Post-datism & $619 \pm 686.98$ & \\
\hline $\begin{array}{l}\text { Gestational/pre- } \\
\text { gestational diabetes }\end{array}$ & $416.67 \pm 236.2$ & \\
\hline \multicolumn{3}{|l|}{ Type of delivery } \\
\hline Normal vaginal & $325.9 \pm 371.14$ & \multirow{4}{*}{$<0.05$} \\
\hline Forceps vaginal & $375 \pm 35.36$ & \\
\hline Elective LSCS & $700 \pm 257.97$ & \\
\hline Emergency LSCS & $631.82 \pm 304.04$ & \\
\hline \multicolumn{3}{|l|}{ Type of uterus } \\
\hline \multicolumn{2}{|c|}{ Non-scarred Primi + G2f 599 \pm 283.33} & \multirow{3}{*}{$<0.05$} \\
\hline $\begin{array}{l}\text { Non-scarred previous } \\
\text { FTND }\end{array}$ & $745 \pm 220.5$ & \\
\hline Scarred previous LSCS & $748.89 \pm 373.2$ & \\
\hline \multicolumn{3}{|l|}{ High risk pregnancies } \\
\hline One high-risk & $436 \pm 248.9$ & \multirow{2}{*}{$<0.05$} \\
\hline$>1$ high-risk & $654.44 \pm 422.7$ & \\
\hline
\end{tabular}

\section{DISCUSSION}

The present observational study assessed mean blood loss in women delivering in our department. Of the 100 cases, 
all actively managed in the third stage of labor with oxytocin, the mean blood loss was $480.2 \pm 366.47 \mathrm{ml}$.

Table 4: Association of various high-risk condition among patients with the amount of blood loss $(n=54)$.

\begin{tabular}{|llll|}
\hline $\begin{array}{l}\text { High risk } \\
\text { conditions }\end{array}$ & $\mathbf{N}$ & $\%$ & Blood loss* \\
\hline Anemia & 1 & $1.85 \%$ & 200 \\
\hline Beta thalassemia trait & 1 & $1.85 \%$ & 340 \\
\hline Chronic hypertension & 1 & $1.85 \%$ & 700 \\
\hline $\begin{array}{l}\text { Gestational } \\
\text { hypertension }\end{array}$ & 4 & $7.41 \%$ & $547.5 \pm 267.753$ \\
\hline Gestational diabetes & 5 & $9.26 \%$ & $376 \pm 190.078$ \\
\hline $\begin{array}{l}\text { Pre-gestational } \\
\text { diabetes mellitus }\end{array}$ & 3 & $5.56 \%$ & $586.67 \pm 210.079$ \\
\hline Hypothyroidism & 15 & $27.78 \%$ & $491.33 \pm 252.435$ \\
\hline Hyperthyroidism & 1 & $1.85 \%$ & 200 \\
\hline $\begin{array}{l}\text { Multipara with prior } \\
\text { history of PPH }\end{array}$ & 1 & $1.85 \%$ & 1020 \\
\hline Placenta previa & 1 & $1.85 \%$ & 1050 \\
\hline Preeclampsia & 11 & $20.37 \%$ & $561.818 \pm 365.59$ \\
\hline RH negative pregnanc & 4 & $7.41 \%$ & $437.5 \pm 165.202$ \\
\hline Sickle cell trait & 4 & $7.41 \%$ & $925 \pm 464.579$ \\
\hline Thrombocytopenia & 2 & $3.70 \%$ & $325 \pm 304.056$ \\
\hline
\end{tabular}

*Mean and standard deviation.

In this study, increasing maternal age appeared to be associated with increasing blood loss, with women aged more than 35 years having significantly higher blood loss $(846 \pm 528.6 \mathrm{ml})$. However, Durmaz and Komurcu found no such relationship in their meta-analysis, which included includs five studies and 1,286,752 women. ${ }^{3}$ In fact, Lao and colleagues also pointed that advanced maternal age only served as a surrogate factor for PPH due to the associated increased risk factors, obstetric complications and interventions. ${ }^{4}$ Their multivariate analysis indicated that aging was actually associated with decreased $\mathrm{PPH}$, the risk decreasing progressively from those aged 25-29 years to those aged $\geq 40$ years compared with the 20-24 years group. One possible explanation could be that most of the studies in the met analysis were conducted in developed countries with good health indicators and effective healthcare systems. Data from developing countries like India is scarce and thus further studies are required.

In addition, we found primipara mothers to have significantly higher blood loss. This is in support of the recently published meta-analysis, which found primiparity of mothers $[\mathrm{OR}=1.37,95 \% \mathrm{CI}(1.35,1.40)]$ to be associated with $\mathrm{PPH}^{2}$ Shechter-Maor and colleagues found that cesarean sections, operative vaginal deliveries and $\mathrm{PPH}$ were more common among the primiparous group. ${ }^{5}$ These studies attributed increased rates of PPH among primiparas to prolonged labors and increased rates of labor induction with long periods of oxytocin administration. In contrast, a recently conducted randomized trial demonstrated an increased incidence of PPH among multigravida deliveries. ${ }^{6}$

Authors found the mean blood loss in the 49 LSCS deliveries to be significantly higher than those in vaginal deliveries and that too among elective LSCS deliveries. Similar results were shown by Ngwenya in a poorresource setting of Zimbabwe. ${ }^{7}$ Sharma and Dhakal from Nepal demonstrated similar pattern as well. ${ }^{8}$ Furthermore, we observed that deliveries who had a spontaneous onset of labor had the least blood loss. Among the various indications of labor induction, we observed women with oligohydramnios and postdatism to have the maximum blood loss. This was in line with previous studies, compared with spontaneous vaginal delivery, the odds of severe PPH were higher among women undergoing either in-labor or planned cesarean delivery. ${ }^{9}$ Reichman et al also observed the prevalence of PPH to be highest for primiparous undergoing operative vaginal delivery $(27 \%)$ compared with multiparous with spontaneous vaginal delivery $(3 \%)$, odds ratio $(\mathrm{OR})=12.8$ [95\% confidence interval (CI), 11.9-13.9]. ${ }^{10}$

Authors observed significantly higher blood loss in patients with chronic hypertension, gestational hypertension, pregestational diabetes mellitus, multipara with prior $\mathrm{PPH}$, placenta previa, preeclampsia and sickle cell trait. A similar pattern was observed by Nyflot and colleagues, who found a history of severe $\mathrm{PPH}$, anticoagulant medication, anemia at booking, severe pre-eclampsia or HELLP syndrome, uterine fibromas, multiple pregnancy and assisted reproductive technologies to be significantly associated with $\mathrm{PPH} .{ }^{11}$ In a case-control study, past history of PPH, pre-eclampsia, labor induction by oxytocin, the absence of managed placental delivery, a gap of more than $30 \mathrm{~min}$ between birth and placental delivery, and macrosomia were found to be significantly associated with PPH. ${ }^{12}$

All cases in the present study received active management of third stage labor with oxytocin and 27 had to be given extra-uterotonics, as these were identified early by using the gravimetric method of measuring blood loss. Early identification and prompt management led to only 12 slipping into PPH (incidence of 12\%). Globally, 2 to $11 \%$ incidence has been reported, while it is 2 to $4 \%$ in vaginal and $6 \%$ after caesarean section in India. ${ }^{13}$ Atonic uterus was the most common cause of PPH in our study, which has been reported by numerous other investigators. ${ }^{12} \mathrm{We}$ managed majority of the cases with conservative medical treatment, with only one case requiring obstetric hysterectomy. Indian data show that $\mathrm{PPH}$ is the most common indication for obstetric hysterectomy. ${ }^{14}$

\section{CONCLUSION}

Study were able to avoid PPH in 15 women by using a reliable method of blood loss measurement and initiating interventions early. Study also identified various maternal risk factors which were associated with the development of 
PPH in our study population. Diagnosing PPH should promptly be followed by all possible interventions within the golden hour. Thus, by following an organised management protocol, specially towards at-risk mothers, morbidity and mortality of the mother and neonate can be prevented.

\section{Funding: No funding sources}

Conflict of interest: None declared

Ethical approval: The study was approved by the Institutional Ethics Committee

\section{REFERENCES}

1. World Health Organization (WHO) recommendations for the prevention and treatment of postpartum hemorrhage. World Health Organization, Geneva. 2012 Available at: https://www.who.int/reproductivehealth/publications /maternal_perinatal_health/9789241548502/en/.

Accessed on $25^{\text {th }}$ January 2020.

2. Begley CM, Gyte GM, Devane D, McGuire W, Weeks A, Biesty LM. Active versus expectant management for women in the third stage of labour. Cochrane Database Syst Rev. 2019;2(2):CD007412.

3. Durmaz A, Komurcu N. Relationship between maternal characteristics and postpartum hemorrhage: a metaanalysis study. J Nurs Res. 2018;26(5):362-72.

4. Lao TT, Sahota DS, Cheng YK, Law LW, Leung TY. Advanced maternal age and postpartum hemorrhage-risk factor or red herring? J MaternalFetal Neonat Med. 2014;27(3):243-6.

5. Shechter-Maor G, Sadeh-Mestechkin D, Paz YG, Halevy RS, Markovitch O, Biron-Shental T. Does parity affect pregnancy outcomes in the elderly gravida? Arch Gynecol Obstet. 2019;25:1-7.

6. Walker KF, Bugg GJ, Macpherson M, McCormick C, Grace N, Wildsmith C, et al. Randomized trial of labor induction in women 35 years of age or older. N Eng J Med. 2016;374(9):813-22.
7. Ngwenya S. Postpartum hemorrhage: incidence, risk factors, and outcomes in a low-resource setting. Inter J Women's Health. 2016;8:647.

8. Sharma S, Dhakal I. Cesarean versus vaginal delivery: an institutional experience. J Nepal Med Associat. 2018;56:209.

9. Al-Zirqi I, Vangen S, Forsen L, Stray-Pedersen B. Effects of onset of labor and mode of delivery on severe postpartum hemorrhage. Am J Obst Gynecol. 2009;201:273.e1-9.

10. Reichman O, Gal M, Sela HY, Khayyat I, Emanuel M, Samueloff A. Grouping parturients by parity, previous-cesarean, and mode of delivery (PC-MoD classification) better identifies groups at risk for postpartum hemorrhage. Am J Perinatol. 2016;33(12):1133-7.

11. Nyfløt LT, Sandven I, Stray-Pedersen B, Pettersen S, Al-Zirqi I, Rosenberg M, et al. Risk factors for severe postpartum hemorrhage: a case-control study. BMC Preg Childbirth. 2017;17(1):17.

12. Firmin M, Carles G, Mence B, Madhusudan N, Faurous E, Jolivet A. Postpartum hemorrhage: incidence, risk factors, and causes in Western French Guiana. J Gynecol Obstet Human Reprod. 2019;48(1):55-60.

13. Kumar N. Postpartum hemorrhage; a major killer of woman: review of current scenario. Obstet Gynecol Int J. 2016;4(4):00116.

14. Bhattacharyya R, Mukherjee K. Emergency peripartum hysterectomy: indications and obstetric outcome (a 5-year review). Int Educat Res J. 2016;2(5):58-60.

Cite this article as: Jain $\mathrm{P}$, Thakur N, Jain A, Agrawal S, Kamra S, Jacob S. Factors associated with increased blood loss during delivery. Int $\mathbf{J}$ Reprod Contracept Obstet Gynecol 2020;9:1213-7. 